Brit. J. industr. Med., 1964, 21, 145.

\title{
AETIOLOGICAL ANALYSIS OF 100 PATIENTS WITH DERMATITIS CLAIMING TO SUFFER FROM PRESCRIBED DISEASE
}

\author{
BY \\ DENIS C. DEVINE \\ From the Department of Dermatology, The Western Infirmary, Glasgow
}

(RECEIVED FOR PUBLICATION JUNE 11, 1963)

\begin{abstract}
Since the National Health Service came into force in 1948, there has been a steady flow of patients referred by the Ministry of Pensions and National Insurance to dermatologists. These patients claim to suffer from a Prescribed Disease, and the dermatologist has to determine whether they have a skin condition produced by certain occupational agents prescribed by the Minister. Basically these have always been dust, liquid, and vapour occurring in occupations where these substances are encountered. Before 1959 Prescribed Disease relating to skin conditions was numbered 24b, but since then it has been numbered 42. This numerical change also carried with it a modification of the definition of the disease and in effect specifically limited diagnosis to cases of non-infective dermatitis.

As Prescribed Disease claimants with skin conditions present a constant diagnostic problem, a survey was made of 100 copies of consecutive reports on patients who had claimed to have Prescribed Disease 24b, to determine the chief aetiological factors involved in this type of dermatological case and to see to what extent the dermatologist could solve the diagnostic problem and how relevant to the issue is non-infective dermatitis as it applies to Prescribed Disease 42.

Patients were within the working age group, 63 being men and 37 women. In 56 patients, in whom the aetiological factors were clearly constitutional or attributable to non-occupational external causes or to industrial injury, Prescribed agents could be firmly excluded as causes of their skin conditions.

In 34 cases, Prescribed agents, which were mainly dusts and liquids, could reasonably be implicated as causes. In the remaining 10 cases, however, evidence for and against these agents as causes was about equal, and the diagnosis was settled by giving them the benefit of the doubt. On a dermatological basis, therefore, $90 \%$ of the diagnostic problem could be solved.

Nine patients in the series were diagnosed as having infective dermatitis due to minor skin trauma initiated by liquids encountered at work. This diagnosis was also in accord with a diagnosis of Prescribed Disease 24b. Since 1959, however, a diagnosis of infective dermatitis has been incompatible with one of Prescribed Disease 42 because this is defined as a non-infective dermatitis. It seems therefore that the definition could be more flexible so as to embrace certain cases of infective dermatitis which can develop from minor skin trauma due to occupational agents.
\end{abstract}

The first Workmen's Compensation Act of 1897 was passed to meet dissatisfaction with the limited protection afforded by the common law when a workman was injured or killed at work, making the employer liable to pay compensation in these cases. The 1906 Act extended the scope of compensation to cover six diseases regarded as of likely occupational origin which, in certain circumstances, would be dealt with as injuries though no accident could be proved. These were scheduled in relation to certain processes of work, and over the years the number increased to 41 diseases.

The Workmen's Compensation Acts were replaced by, and formed the basis of, the National Insurance (Industrial Injuries) Act, 1946, and, when it came into operation on July 5,1948 , the Scheduled Diseases were superseded by broadly smilar conditions called Prescribed Diseases. These comprise certain diseases and special injuries which are set out numerically in schedules as diseases prescribed by 
the Minister in relation to insured persons in Prescribed occupations or classes of occupation.

Prescribed Disease with regard to skin conditions was numbered $24 \mathrm{~b}$ of the first schedule and defined as inflammation or ulceration of the skin produced by dust, liquid or vapour (including the condition known as chlor-acne but excluding chrome ulceration)', occurring in occupations where these substances were encountered. Subsequent minor amendments modified the definition, but in 1959 a major change essentially defined this disease as 'noninfective dermatitis' and placed it 42 in the schedule where it is described as "non-infective dermatitis of external origin (including chrome ulceration of the skin but excluding dermatitis due to ionising particles or electro-magnetic radiations other than radiant heat), occurring in occupations where there is exposure to dust, liquid, or vapour or any other external agent capable of irritating the skin (including friction or heat but excluding ionising particles, or electro-magnetic radiations other than radiant heat)'.

Since the National Insurance Act became effective in 1948, certain patients with skin disorders claiming to suffer from Prescribed Disease have been referred by the Ministry of Pensions and National Insurance to dermatologists who have to determine if they have, or have had, wholly or partly, a skin condition produced by dust, liquid, or vapour or other specified agents encountered at work. Over the years the number of these patients presenting to dermatologists for examination has been considerable. It was therefore thought worth while to analyse copies of the personal reports on 100 such patients in an endeavour to determine the aetiological factors involved in the dermatological diagnosis in this particular group of patients and the extent in fact to which the problem could be solved. Reports were written on Government Form B.1. 161A on which the specialist is asked to furnish his opinion. The patients came from Glasgow and the west of Scotland and had been seen consecutively before 1959. Any opinion given therefore was in accordance with the then current definition of Prescribed Disease $24 \mathrm{~b}$, which did not restrict positive diagnosis to non-infective dermatitis as does the present definition 42. In fact it was found in the series that infective dermatitis had been frequently ascribed to Prescribed factors as well as to industrial injury and non-occupational factors.

Infective dermatitis as used in the present context is synonymous with what Engman (1902) originally described as an infectious form of an eczematoid dermatitis', now often called 'infectious eczematoid dermatitis' (Sutton, 1920; Ormsby and Montgomery, 1948; Sutton, 1956). This condition is a dermatitic process of probable bacterial origin which arises at the site of trauma, accidental, surgical, thermal, or chemical or apparently de novo, in which case it starts as a vesicle, pustule, or erythematous, scaly or crusted point or plaque. Characteristic of the disease is its peripheral extension in well-defined patches, its asymmetry, and the tendency for other areas to develop.

All patients in the series, 63 of whom were men and 37 women, were grouped broadly under two headings, depending on whether the condition had been accepted as attributable to employment or not. They were further sub-grouped according to the particular aetiological factors implicated.

\section{Non-attributable Group}

Forty-seven patients were placed in this group (Table 1). Of these, 28 presented with infective and constitutional states such as scabies, erythema multiforme, ichthyosis, pompholyx, and tinea pedis.

TABLE 1

NON-ATTRIBUTABLE CASES

\begin{tabular}{|c|c|}
\hline Condition & $\begin{array}{l}\text { No. of } \\
\text { Patients }\end{array}$ \\
\hline $\begin{array}{l}\text { Urticaria } \\
\text { Scabies } \\
\text { Erythema multiforme } \\
\text { Pompholyx } \\
\text { Tinea pedis } \\
\text { Nummular eczema, sensitization dermatitis, palmar } \\
\text { eczema } \\
\text { Ichthyosis } \\
\text { Seborrhoeic dermatitis } \\
\text { Impetigo and ecthyma } \\
\text { Dermatitis venenata } \\
\text { Infective dermatitis }\end{array}$ & $\begin{array}{r}2 \\
2 \\
1 \\
8 \\
4 \\
3 \\
1 \\
3 \\
4 \\
4 \\
15\end{array}$ \\
\hline Total & 47 \\
\hline
\end{tabular}

A diagnosis of dermatitis venenata was made in three patients who had severe chapping of the hands, probably due to domestic grease solvents, and in another in whom dermatitis had begun around a recently sprained ankle which had been treated by mustard to which the skin had previously reacted. A diagnosis of non-occupational infective dermatitis was made in 12 patients in whom circumscribed dermatitis had spread out from small spots which had apparently appeared de novo. In three others this dermatitis had extended out from a cellulitis, a pustule, and an old operation wound respectively.

\section{Attributable Group}

Patients included under this heading (Table 2) were those in whom the dermatitis was attributed to working conditions and they fell into the following two categories. 
TABLE 2

ATTRIBUTABLE CASES

\begin{tabular}{|c|c|c|}
\hline Injury & Occupation & $\begin{array}{l}\text { No. of } \\
\text { Patients }\end{array}$ \\
\hline $\begin{array}{l}\text { (a) Infective Dermatitis At- } \\
\text { tributed to Industrial } \\
\text { Injury } \\
\text { Abrasions and lacera- } \\
\text { tions }\end{array}$ & $\begin{array}{l}\text { Printer } \\
\text { Bus conductor } \\
\text { Coalminer } \\
\text { Engineer's labourer } \\
\text { Paper printer } \\
\text { Railway porter } \\
\text { General labourer } \\
\text { General labourer }\end{array}$ & $\begin{array}{l}1 \\
1 \\
2 \\
1 \\
1 \\
1 \\
1 \\
1\end{array}$ \\
\hline & Total & 9 \\
\hline $\begin{array}{l}\text { (b) Dermatitis Attributed to } \\
\text { Prescribed Agents (24b) } \\
\text { Soap, detergent, alkali } \\
\text { solutions, and wet } \\
\text { work }\end{array}$ & $\begin{array}{l}\text { Laboratory cleaner } \\
\text { Bus cleaner } \\
\text { Canteen worker } \\
\text { Domestic help } \\
\text { Hospital maid } \\
\text { Hairdresser } \\
\text { Office cleaner } \\
\text { School cleaner } \\
\text { Glue worker } \\
\text { Cardboard carton maker } \\
\text { Laundry worker } \\
\text { Trawler hand }\end{array}$ & $\begin{array}{l}1 \\
1 \\
3 \\
1 \\
1 \\
1 \\
4 \\
2 \\
1 \\
1 \\
1 \\
1\end{array}$ \\
\hline & Total & 18 \\
\hline \multirow[t]{2}{*}{ Cement } & Cement worker & 3 \\
\hline & Total & 3 \\
\hline \multirow[t]{2}{*}{ Oils } & $\begin{array}{l}\text { Driller } \\
\text { Nut and bolt inspector } \\
\text { Machine operator } \\
\text { Metal cutter }\end{array}$ & $\begin{array}{l}3 \\
1 \\
1 \\
1\end{array}$ \\
\hline & Total & 6 \\
\hline \multirow[t]{2}{*}{ Dusts as friction agents } & $\begin{array}{l}\text { Bricklayer } \\
\text { Coalminer } \\
\text { Iron filer }\end{array}$ & $\begin{array}{l}1 \\
8 \\
1\end{array}$ \\
\hline & Total & 10 \\
\hline \multirow[t]{2}{*}{$\begin{array}{l}\text { Miscellaneous substances } \\
\text { Methyl iodide } \\
\text { Sulphonamide } \\
\text { Creosote } \\
\text { Hay } \\
\text { Dye } \\
\text { Aircraft paint } \\
\text { Dye trade sensitizer }\end{array}$} & $\begin{array}{l}\text { Chemical worker } \\
\text { Chemical worker } \\
\text { General labourer } \\
\text { Farm worker } \\
\text { Chemical worker } \\
\text { Aircraft worker } \\
\text { Joiner }\end{array}$ & $\begin{array}{l}1 \\
1 \\
1 \\
1 \\
1 \\
1 \\
1\end{array}$ \\
\hline & Total & 7 \\
\hline
\end{tabular}

Ascribed to Industrial Injury.-The nine patients in this category (Table $2 a$ ) were diagnosed as having infective dermatitis because circumscribed eczematoid lesions had spread out from accidental burns, abrasions, and lacerations sustained at work. Though the dermatitis in these patients did not satisfy the definition of Prescribed Disease, it appeared to be due to occupation, and a note to this effect was entered in the reports.

Ascribed to Prescribed Agents (24b).-Forty-four cases were ascribed to these agents (Table $2 b$ ), and, with the exception of one attributed to hay, all were credited to dusts or liquids. A minority presented features of typical contact dermatitis, and oil folliculitis was the only specific lesion encountered.

Agents implicated were soaps, detergents, alkali solutions, wet work, cement, oils, dusts acting as friction agents, and miscellaneous substances acting as probable sensitizers.

Soap, Detergent, Alkali Solutions, and Wet Work.-These were deemed causal in 18 claimants, mainly cleaners and others engaged in wet work. Four had patches of dryness and cracking or actual fissuring of the skin of the hands and fingers consistent with defatting effects (Schwartz, Tulipan, and Birmingham, 1957). Another nine presented asymmetric circumscribed eczematoid patches of the upper extremities. As such these were not characteristic of fat-solvent reactions, but the histories revealed that they had spread out from foci of probable fat-solvent skin change such as fissures or small areas of dryness and superficial cracking. They were accepted therefore as infective dermatitis due to the above agents. Five patients developed chronic nonspecific symmetrical dermatitis of the hands and fingers after exposure to these potential irritants and they were given the benefit of the doubt because, though a constitutional cause seemed possible, none could be implicated.

In housewives, whose dermatitis seemed to be due to wet work and grease solvents, it often appeared that the cause should be apportioned partly to domestic factors.

Cement.-Three cases were attributed to cements, exposure to which had been followed by dryness and cracking of the skin of the hands and fingers, thought to be consistent with the defatting or hygroscopic effects of these substances (Schwartz et al., 1957).

Oils.-Six cases were attributed to lubricating, coolant, and penetrating oils in drillers and others whose skin and clothing had been in contact with these liquids. Only two had characteristic folliculitis and acne-form eruptions of the forearms and lower limbs. Four patients had dryness and fissuring of the back of the hands considered to be in keeping with the defatting effects of paraffin oils (Schwartz et al., 1957); one was a housewife in whom domestic grease solvents probably played a part.

Dusts Acting as Friction Agents.-These were implicated in 10 patients, eight being coalminers, one an iron filer, and the other a bricklayer. In none did dust appear to exert a specific effect. It was accepted as probable that dust and sweat in conjunction with working conditions had damaged the skin by friction.

The bricklayer, engaged alternately in wet and dry sandy conditions, developed dermatitis of the calves 
where sand had collected under his clothing at sites rubbed by his Wellington boots. In six of the coalminers, the dermatitis showed a predilection for main friction areas, such as the waist, ankles, and below the knees where constricting straps were sometimes secured. In the other two miners, extensive dermatitis of the trunk and limbs had been diagnosed as Prescribed Disease soon after the onset. When seen, however, the dermatitis had persisted long after they had ceased work. The original diagnosis therefore could have been wrong, or chronicity could have been due to resulting continuing sensitization. The latter possibility was accepted to give them the benefit of the doubt. The diagnosis was settled similarly in the case of the iron filer, who contracted non-specific symmetrical dermatitis of the sides of the fingers after several weeks' contact with iron filings and whose condition could have been due equally to the latter or to another cause.

Four of the coalminers sweated excessively and three had seborrhoeic states, respectively, pityriasis capitis, seborrhoeide, and marginal blepharitis.

Miscellaneous Substances.-A contact origin was accepted when acute dermatitis developed on parts exposed to known or suspected sensitizers and usually cleared quickly in their absence; this involved seven patients.

Two attacks of local bullous dermatitis, one on the forearms and another on the dorsa of the feet, occurred in a chemical worker at sites splashed by implicated methyl iodide, a patch test being positive. Acute diffuse dermatitis of the face, neck, forearms, and hands in another chemical worker was attributed to sulphonamide dust, and in a general labourer to creosote. In an agricultural worker, progressively more extensive dermatitis starting on the sides of the fingers and finally involving the hands, forearms, face, neck, and trunk and occurring every July for eight years after handling hay, was assigned to the latter. A yellow dye was blamed in yet another chemical worker; contact with this dye on several occasions had been followed by blisters on the sides of the fingers and redness and swelling on the backs of the hands. An aircraft worker, who had handled an aircraft paint for three years, had chronic lichenified dermatitis of the backs of the hands throughout; this cleared quickly when he ceased work. The diagnosis could equally well have been contact dermatitis or neuro-dermatitis, and the problem was again settled by giving him the benefit of the doubt. This was also given to a joiner, who developed extensive dermatitis after handling chemically contaminated wood in a dye factory because of his possible contact with numerous sensitizers of dye manufacture, no other cause being apparent.

In the present series of 100 patients claiming to suffer from Prescribed Disease 24b, Prescribed agents could be firmly excluded in 56 patients because the skin condition was constitutional or very probably due to non-relevant extraneous factors. In the remaining 44 patients, Prescribed agents were implicated with varying degrees of conviction. In only two of these patients did skin lesions seem to be specific reactions to the agents encountered, viz. those with oil folliculitis. In another 32 patients implication of agents could reasonably be based on feasible premises. These were five patients in whom the clinical features were linked with potential skin sensitizers; 11 with defatting effects on parts exposed to soaps, detergents, alkali solutions, paraffins, and cements; seven with dermatitis involving maximum dust friction sites; and nine in whom infective dermatitis developed from minor skin trauma probably caused by wet work and grease solvents. In the remaining 10 patients it was impossible to say if Prescribed agents had caused their skin conditions because criteria for and against their involvement were almost equal. In these patients the diagnosis was settled by giving claimants the benefit of the doubt.

It emerged therefore that the diagnostic problem could be solved dermatologically in $90 \%$ of the patients in the series by a rational 'yes' or 'no' to the question of the relevance of Prescribed agents.

It will be recalled that these cases were collected before 1959, and therefore any opinion expressed was in accordance with the definition of Prescribed Disease 24b, which did not exclude infective dermatitis. In nine patients a diagnosis was in fact made of infective dermatitis attributable to occupational liquids which at the same time was compatible with a diagnosis of Prescribed Disease. It is interesting to note that, strictly speaking, these cases could not now qualify for a diagnosis of Prescribed Disease, viz. 42, because the definition, as it stands, limits positive diagnosis to conditions which are due to non-infective dermatitis. In the latter connexion the Industrial Injuries Advisory Council, 1958, explains that, Prescribed Disease 42 being in very general terms a condition of external origin, diagnosis must be limited to non-infective dermatitis to exclude infection such as impetigo and epidermophytosis which it saw no reason to include. Observations in the present series suggest, however, that such a restriction might be too rigid since it can exclude a recognized form of dermatitis which, theoretically at least, is an infective dermatitis and can be initiated by minor skin trauma attributable to occupational liquids such as solutions of soaps, detergents, and alkalis. 


\section{REFERENCES}

Engman, M. F. (1902). Amer. Med. (Philad.) iv; 769.

Ministry of Pensions and National Insurance (1955). Report of the Departmental Committee Appointed to Review the Diseases Provisions of the National Insurance (Industrial Injuries) Act, 1946. Cmd. 9548. Pp. 1, 3, 4, 6, 18. H.M.S.O., London.

Ministry of Pensions and National Insurance (1958). Review of The Prescribed Diseases Schedule. Report of the Industrial Injuries Advisory Council in accordance with Section 61 of the National Insurance (Industrial Injuries) Act, 1946, on the National Insurance (Industrial Injuries) Act, 1946, on the
question of whether any adjustments should be made in the terms of prescription of Prescribed Diseases other than Pneumoconiosis and Byssinosis (April, 1958). Pp. 12, 13. H.M.S.O., London.
Ministry of Pensions and National Insurance (1961). The Law relating to National Insurance (Industrial Injuries): The Statutes, Regulations and Orders as now in Force. Ed. by Brockman, J. St. L., Vol. 1, Pp. 1, 411, 434. H.M.S.O., London. Ormsby, O. S., and Montgomery, H. (1948). Diseases of the Skin. 7 th ed., Pp. 295-298. Kimpton, London.

Schwartz, L., Tulipan, L., and Birmingham, D. J. (1957). Occupational Diseases of the Skin, 3rd ed., Pp. 251, 258, 327, 353. Kimpton, London.

Statutory Instruments (1948). No. 1371. The National Insurance (Industrial Injuries) (Prescribed Diseases) Regulations, 1948: Pt. 2, para. 4: 1st sched., pt. 1. H.M.S.O. London.

(1959) No 467. The National Insurance (Industrial Injuries) (Prescribed Diseases) Regulations, 1959: 1st sched., pt. 1. (Prescribed Diseases)

Sutton, R. L. (1920). J. Amer. med. Ass., 75, 976.

Sutton, R. L., Jr. (1956). Diseases of the Skin, 11th ed., p. 270. Mosby, St. Louis. 